https://doi.org/10.18485/iipe_response2covid19.2021.ch19

\title{
COUNTRIES' APPROACH TO COMPULSORY LICENSING IN THE TIME OF THE COVID-19 PANDEMIC
}

\begin{abstract}
Milorad Stamenović ${ }^{1}$
Abstract: This paper deals with compulsory licensing for pharmaceuticals based on the TRIPS Agreement during the COVID-19 pandemic. Considering that the vaccines are under patent protection, and a pandemic is in effect, questions are arising about the timely delivery of the new vaccines on a global level at the time of a global health crisis. In this research, we provide an additional view on the question of the approach of the selected countries to compulsory licensing in the time of the COVID-19 pandemic. We examined multiple cases of countries and their approach to compulsory licensing during the pandemic, and we assessed examples of compulsory licensing in the past regarding antiretroviral therapy. We are also interested in understanding countries' profiles considering the pandemic through factors that have potentially triggered decisions in preparation for compulsory licensing or in initiating such a request. To address this question, we use inductive and deductive methods in the analysis and synthesis of the observed literature, including a statistical showcase of the data. The results put additional light on the selected factors impacting countries' decisions for compulsory licensing and the approaches of the observed countries/cases to the compulsory licensing considering national legislation and pandemic effects on the observed country.
\end{abstract}

Keywords: TRIPS Agreement, compulsory licensing, COVID-19, national legislation, vaccine.

\section{INTRODUCTION}

The SARS-COV2 virus has marked the previous period since the end of 2019. With its spread from China to the territory of Italy and later to all countries of the world, a global pandemic never before seen in the recent history of mankind was

\footnotetext{
${ }^{1}$ Research Fellow, SKEMA Business School, Francois Grosso 7, Nice, France, milorad.stamenovic@skema.edu.
} 
created. This pandemic has definitely had and still has an extremely negative and strong impact on all areas of society, such as the economy, health, politics and others. However, two aspects are important for this chapter, namely the health of the population and the consequences for economic development in the context of finding solutions to reduce the impact of the COVID-19 pandemic. The World Trade Organization (WTO) provides opportunities for its member states to obtain the necessary pharmaceuticals for their populations in crisis situations through the flexibilities provided by the TRIPS Agreement.

In this chapter, we analysed the characteristics of countries that have tried to obtain the necessary pharmaceuticals for their populations through these arrangements. We focused on the flexibility provided by Article 31 of the TRIPS Agreement - compulsory licensing. It is important to note that the countries that sought to obtain the necessary drugs in 2020 did not yet have enough information about the best way to treat patients and combat the pandemic because the scientific community worked effectively globally during 2020 and 2021 to reach adequate solutions. However, it is interesting that some countries (e.g., Israel and Russia) have sought the solution to the SARS-COV2 treatment with drugs like lopinavir/remdesivir (which belong to the group of antiretroviral drugs and have positive effects on HIV/AIDS infections). Russia and Israel did not seek these drugs because of HIV/AIDS infections in their populations (as other countries did in the past), but because of a mechanism of action that was thought to be able to help treat COVID-19. For this reason, we are interested in analyzing selected countries from the angle of their desire to enter compulsory licensing for the same type of drug but with different indications. This procedure arose due to the impossibility of solving the current problems caused by the COVID-19 pandemic, as well as the fact that the vaccines that were made were not approved as a public good. This was a decision made at the 73rd World Health Assembly (18-19 May 2020). In principle, it is defined that in addition to the fact that newly created vaccines that are necessary for humanity cannot be considered a public good, they fall under the regulations on patent protection regardless of the severity and significance of the current COVID-19 pandemic. This resolution, however, recognized the importance of immunization as a public good, which is paradoxical if it is understood that vaccines themselves are not. Interestingly, the EU has advocated (with the support of about 100 countries) defining vaccines as a public good. However, the US has rejected and reformulated this request (Third World Network, 2020).

There were also other initiatives for finding solutions in the field of vaccination at the global level. Therefore, Costa Rica and the World Health Organization created the action (The solidarity call to Action) in order to approve the voluntary licensing 
of the drug for COVID-19 when it becomes available without being directly linked to Article 28 of the TRIPS Agreement which defines exclusive rights (WHO, 2020).

In addition to the problem of patent rights to newly created drugs (or vaccines), there is also the problem of their production and distribution (Stamenovic, 2020; Stamenovic, 2020a). In these processes, the production capacities of the patent holder are especially questionable, as well as the regulations that should ensure the timely delivery of pharmaceuticals to countries around the world. In addition, a significant problem is related to the patients themselves, i.e., those infected with the SARS-COV2 virus. In particular, healthcare treatments are very expensive in some countries, such as the United States, raising concerns about their availability in pandemics and the amount of debt that patients will incur if they are fortunate enough to recover from this virus. Access to health care is not only a problem in countries where treatment is expensive, but mostly it is problematic in underresourced and poor states globally. If we look at the high-risk rate of low-income citizens, there is, of course, a risk for underdeveloped and developing countries around the world. Also, special attention should be paid to chronic patients whose chronic diseases have affected their immunity or who need to be treated in health care facilities when this is not possible due to COVID-19 and due to the small capacity of the domestic health care system. Patients whose immunity is particularly at risk, such as patients with chronic lung disease, malnutrition or compromised immunity due to HIV, should also be borne in mind.

Therefore, the idea of the TRIPS Agreement is that countries with insufficient funds or, for some other reason, unable to provide therapy to their populations in times of health crisis have the opportunity to activate some of the flexibility offered by this global agreement. In addition to the resources themselves or the inability to come up with innovative solutions within the time needed to resolve the health crisis, the WTO member states can find a solution through the production of generic pharmaceuticals or import options. Compulsory licensing is one of the flexibilities we are most interested in exploring in this chapter. The production of a generic drug through compulsory licensing can be made without the prior approval of the patent holder. Compulsory licensing has been used 108 times in history, according to the available data (Medicines Law \& Policy, 2021). Among other things, it was used to help the WTO members find better options for HIV/AIDS infections in times of health crisis (WTO, 2021).

During 2020, the situation was quite unreliable although there was a continuous intervention by the World Health Organization (WHO) in order to coordinate and manage the crisis on a global level. When the scientific discoveries of vaccines came about, the drugs that were studied fell into the background. It was necessary to execute clinical trials, which were made at a speed that was unknown to the industry 
until then (Ćuzović et al., 2019, pp 184-187; Jelisavac Trošić et al., 2018, pp 83-85). This is evidenced by the decisions of the President of the US, Donald Trump, who with his team and the Food and Drug Agency worked on the introduction of the socalled Operation warp speed into the regulations of clinical studies through a publicprivate partnership in order to bring clinical studies to an end as soon as possible and the vaccine to be ready for use.

Pfizer-Biontech, Jonson \& Johnson, Astra Zeneca, Russian Sputnik V and Chinese Sinopharm started the race. In the later phase of 2020, the COVAX centre was implemented, formed by Gavi, the coalition for Epidemic Preparedness (CEPI) and the World Health Organization to accelerate the development and production of the COVID-19 vaccines and assure global access. In the further course of our work, we will present the status of vaccination in selected countries, but one of the basic questions we ask is related to improving the flexibilities of the World Trade Organization in such a way that it can really provide timely access to medicines during health crises. The Balkan countries, for example, have demonstrated a completely different approach to vaccination, namely their ability to obtain vaccines under new market conditions. The Republic of Croatia, as an EU member, was forced to wait for EU solutions while Bosnia and Herzegovina, which is not an EU member, did not have the opportunity to get vaccines through other channels. The same was true for smaller countries such as Montenegro and North Macedonia. On the other hand, the Republic of Serbia is among the countries in the world that was the first to get a significant number of vaccines, and it has four types of vaccines to offer to its citizens. However, the Republic of Serbia is still in the WTO membership negotiation process (Jelisavac Trosic, 2020); (Rabrenovic et al., 2020). It is wellknown that there are many variations of the coronavirus in nature, but only a few have the possibility of transmission to humans. This speaks volumes of the potential danger of viruses in the future, as well as the possible use of viruses in bioterrorism. These are the facts all the great world powers are aware of and which define their security strategies in accordance with the significance of these threats in the future and aimed at better solving health and other crises.

\section{The TRIPS Agreement and Compulsory Licensing}

Compulsory licensing is a part of the TRIPS Agreement (The Agreement on Trade-related Aspects of Intellectual Property Rights), which regulates minimum standards in a legal context for approaching pharmaceutical patents in times of health crisis (WTO, 2021). The TRIPS Agreement became effective on January 1 , 1995, and, to date, is the most affordable agreement in the field of intellectual property. This agreement specifically refers to copyright and related rights and 
requires signatory countries to always harmonize the latest agreements in the field of patent rights, the Paris Convention for the Protection of Industrial Property and the Berne Convention for the Protection of Literary and Artistic Works. The Doha Declaration held in 2001 introduced Article 31bis, which looks at the possibility of applying flexibilities in crisis situations if the state does not have the capacity to produce a particular drug. Thus, under compulsory licensing, the state has the ability to produce a generic drug but only if it is for domestic use. This possibility is not valid if the state would deal with the export of a certain generic drug. The patent holder is not disenfranchised in that case, but there is a possibility that certain fees will be paid through compulsory licensing in order to compensate for the use of the copy of the patent to the patent holder. Although the TRIPS Agreement does not define the use of generic drugs during crisis situations, the 2001 Doha Declaration introduced that the state is able to determine if a public health crisis is a reason for requesting compulsory licensing.

The TRIPS Agreement allows several different flexibilities, which might be achieved through Article 30, Article 31, Article 31bis, and Part 7. This chapter is mostly interested in the area of Article 31, which represents compulsory licensing. Other articles might be connected with this one, especially Article 31bis when the state refers to the fact that there are not enough production capacities for a certain pharmaceutical in times of health crisis.

In the case of the COVID-19 pandemic, although it was a major public health crisis, only a few states have applied for compulsory licensing for drugs that could help their population. Some countries have drafted national regulations to provide a framework in the event that the situation becomes severe enough to necessitate compulsory licensing. Other countries (i.e., France) have held Senate debates on these topics, with differing views on the likelihood of acquiring an effective medication or vaccine through compulsory licensing, despite the worldwide public health crisis.

Regarding national legislation, it is noted that the WTO members who are entitled to use the TRIPS Agreement flexibilities have more significant and stricter national regulations concerning patents. It is for this reason that states are not defining their national legislation in relation to the TRIPS flexibility for compulsory licensing. As a result, some of the nations discussed in this chapter have only recently begun to fully regulate national legislation in order to prepare for compulsory licensing in the event of a COVID-19 crisis situation.

In addition to the above-mentioned Agreement, it is important to keep in mind the production capacities of countries as well as their ability for timely distribution, which is in accordance with international law. Therefore, special agreements should be considered in order to gain insight into international legal relations that could potentially stimulate or have disincentive impact on the production and export of 
vaccine drugs to distant countries (for example, the US-China Economic and Trade Agreement, European Patent Convention and the Patent Cooperation Treaty, Trilateral Cooperation (on patent) and IP5 Cooperation etc.) (USTR.gov, 2020; EPO, 2020).

\section{METHODOLOGICAL FRAMEWORK}

This chapter uses analysis and synthesis of literature based on previous experiences of selected countries in compulsory licensing application processes. We focused on countries that initiated compulsory licensing during the COVID-19 pandemic, whether they requested compulsory licensing in those countries or worked on National Legislation to meet the administrative and regulatory requirements for compulsory licensing proposals. Therefore, the following countries were selected: Canada, Chile, Ecuador, Hungary, Israel, Russia, and France, which indicated the need and desire to be included in the compulsory license process if circumstances so require, and thus reach COVID-19 pharmaceuticals during the public health crisis. Also, it turned out that the required drugs had, in some cases, similarities with antiretroviral therapy in HIV/AIDS, which is why we have presented in the following segment of the work a historical overview of these countries that have such a requirement through compulsory licensing to show the historical component. We presented the impact of pandemic factors reflected in the number of total patients during 2020, the number of total deaths from COVID-19 during 2020, and the number of vaccinated citizens for each of the countries during 2020 and 2021 (concluding with the 1st of June 2021). With this data, we shed additional light on the impact of the COVID-19 pandemic on the observed countries requesting compulsory licensing and thus determine whether and to what extent the COVID19 pandemic pressure on population health played a significant role in the decisionmaking process for compulsory licensing opportunities.

Graph 1. Theoretical framework of the variables impacting government decision on compulsory licensing (prepared by Author)

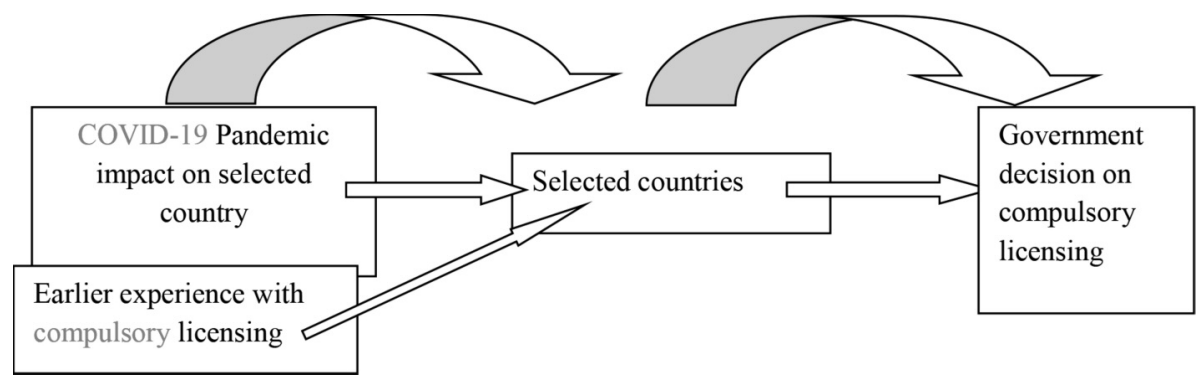


In addition, the economic parameter of the pressure on real GDP is presented, as well as data related to GDP growth during 2019 and 2020 (i.e., a decrease in percentage points as a result of the global public health crisis). These are also parametric that can influence the decision to use compulsory licensing. It is important to note that previous experience in cooperation with the WTO and the use of their flexibility, especially compulsory licensing, is also observed. Of the selected countries, Ecuador, Russia and Chile had previous experience, while France, Hungary and Israel were not in the field of previous compulsory licensing requirements.

\section{RETROSPECTIVE ANALYSES OF COUNTRIES' EXPERIENCES WITH COMPULSORY LICENSING}

According to our analysis, 108 applications have been filed for compulsory licensing (from 2000 until 2021) so far (Medicines Law \& Policy, 2021). These requirements have been submitted for different reasons for different types of drugs, as well as for different therapeutic indications. The cases of Thailand and Brazil in compulsory licensing applications are well-known. Namely, in the case of Thailand, the state requested antiretroviral therapy for HIV/AIDS (efavirenz produced by Merck). To understand the importance of compulsory licensing not only in terms of the timely treatment of patients but also in terms of price, we can cite the example in which Merck offered for efavirenz a price per patient per year of therapy of USD 500, but the Thai government refused and requested a compulsory license from India for USD 224 per patient per year of treatment. A similar situation was with lopinavir/ritonavir, for which, through negotiations with Kaletra (Abbvie) as a patent holder, the Thai government received a price of USD 2,200 per patient per year of treatment, while through compulsory licensing in 2007, it received generic drugs at a cost of USD 676 per patient per year of treatment (price per patient year - PPPY) (Wong, 2020). Thus, compulsory licensing, in this case, helped with the drugs to treat a significant HIV/AIDS health crisis in Thailand, and their price is twice as high in the first case, while in the second case it is more than three times cheaper than the market price agreed with patent holders. Nobel laureate Joseph Stiglitz's comments on this case are well-known when he states that patent protection is like protection of the right to knowledge but also as a death warrant for thousands of people in the poorest countries of the world (Stiglitz, 2007).

If we look at the total number of requests for flexibilities related to pharmaceuticals through the TRIPS Agreement, we can notice that the largest number of requests went through compulsory licensing and Article 31, and we had 
a total of 108 requests (until 2021). We then had 47 requests that went through Part 7 of the TRIPS Agreement, while for Article 30 there were 3 and for Article 31bis one.

Graph 2. Number of requests per type of flexibility (data including 2020), prepared by the author based on data available at Medicines Law \& Policy, (2021)

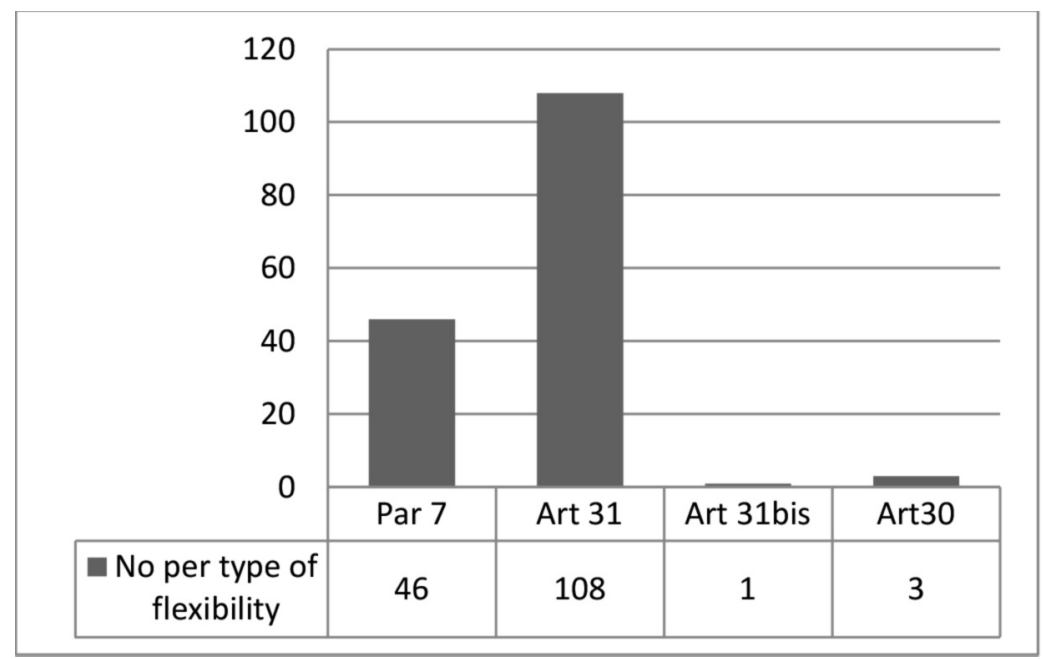

To understand the benefits of compulsory licensing, here are examples from the previous practice. As mentioned regarding Article 31, we have identified 108 applications for compulsory licensing. These requests were related to a variety of medical indications, so 72 requests were for HIV/AIDS; 2 for Anthrax; 2 for Avian Flu; 1 for Bacterial infection; 14 for Cancer; 1 for Cardiovascular disease; 1 for Cystic Fibrosis: 1 for H1N1; 5 for HCV; 1 for Kidney transplant; 1 for Leprosy; 1 for Migraine; 1 for Opioid overdose; 2 for Rheumatoid Arthritis; 1 for Spinal muscular atrophy and 1 for Diabetes II. 
Graph 3. Number of Article 31 requests per World region, prepared by the author based on data available at Medicines Law \& Policy, (2021)

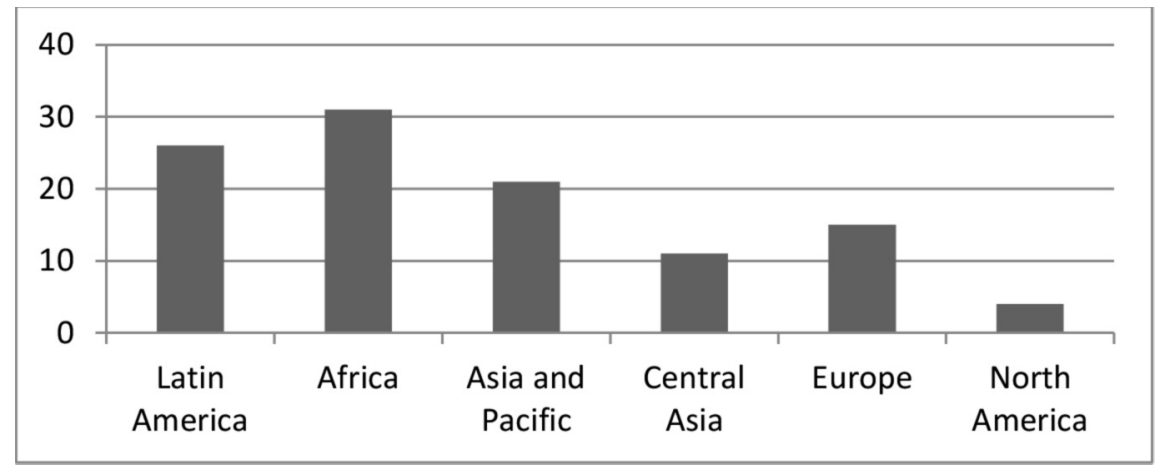

Graph 3 shows the number of compulsory licensing requirements in relation to the world's regions. The largest number of requests originates from the region of Africa (73), followed by Latin America (27), the Asia-Pacific region (27), Europe (16), Central Asia (11), while the smallest number of requests came from the region of North America (5). According to this data, it can be concluded to a certain extent that the poorer regions of the world have submitted more requests for compulsory licensing, although the European region also has a considerable number. 
Graph 4. Number of Article 31 requests per country

(selected highest ranked countries per World region), prepared by the author

based on data available at Medicines Law \& Policy, (2021)

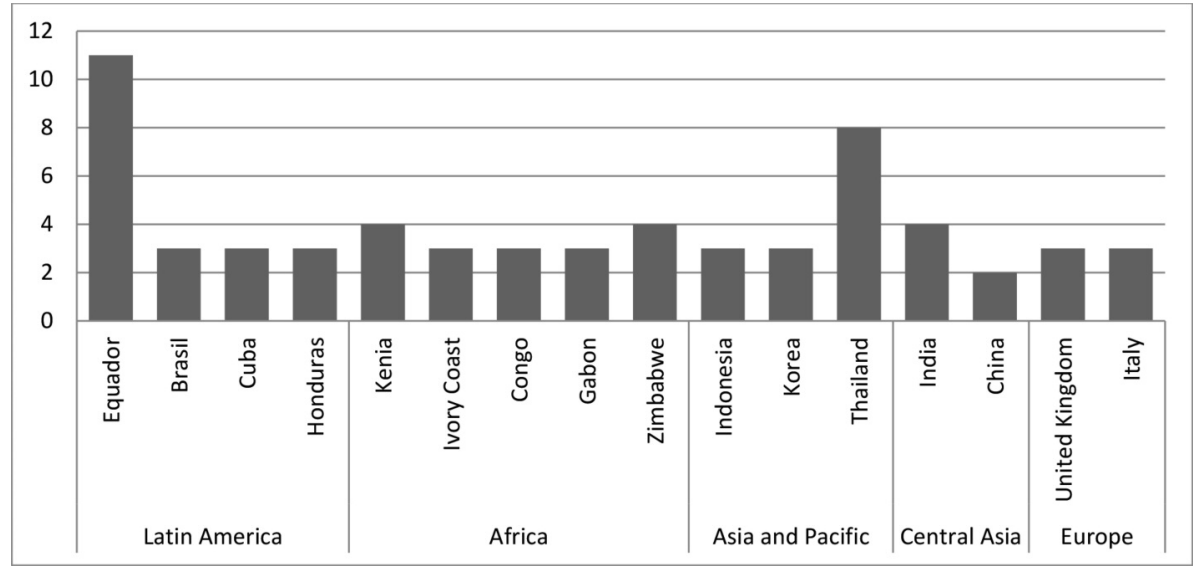

Within Graph 4, which is a continuation of the previous Graph 3, we showed the countries most interested in compulsory licensing in the past. The highestranked is Ecuador with 11 requests, while Thailand has 8 . Countries with 4 requests are Kenya, Zimbabwe, and India, while countries with 3 requests are Brazil, Cuba, Honduras, Ivory Coast, Congo, Gabon, Indonesia, Korea, the United Kingdom, and Italy. China has 2 requests for compulsory licensing.

\section{COMPULSORY LICENSING AND THE COVID-19 PANDEMIC}

It is evident that the TRIPS Agreement and compulsory licensing might have important benefits in terms of public health, and it would be important to use it as much as possible in the future, especially in cases when public health crisis situations are defined. It is also evident that the COVID-19 pandemic is a public health crisis par excellence. However, flexibilities in this situation for drugs/vaccines have been used minimally. Thus, during 2021, compulsory licensing was requested by Hungary, Russia, and Ecuador, and during 2020 it was requested by Israel for the COVID-19 pandemic. Hungary and Russia requested remedisavir for treating COVID-19 and Ecuador requested a generic drug as a replacement for raltegravir (for HIV/AIDS treatment). Interestingly, although the Hungarian government decided to use compulsory licensing for the drug for COVID-19, the drug was actually supplied by 
Richter, where the Hungarian government has $5.25 \%$ of shares, and entered into negotiations with the company to produce the required drug on Hungarian soil.

Israel issued a compulsory license on March 24, 2020, to import generic versions of Abbvie's lopinavir/ritonavir because Israeli authorities have established that an antiretroviral drug could have the potential to treat patients with COVID19. In this case, the problem was not in the payment but in the insufficient amount that the company that owns the patent rights could deliver to Israel in a timely manner. Other countries, on the other hand, sought medications during the COVID19 pandemic owing to the lack of funding rather than the patent holder's incapacity to make and supply the drugs. However, the patent holder, Abbvie, denied such a request by Israel (Kass, 2020).

It is important to note that several other states, such as Canada, Ecuador, and Chile, have prepared legal ground for applying for compulsory licensing. In France, this topic was discussed in the Senate. The French created a kind of dualism in the philosophical approach to this topic and agitated for "Levée des brevets" ("removal of patents"), while the term "global public goods" was considered and criticized in addition to the influence of the United States to reject the EU request for vaccines to be considered a public good. In contrast, they were considered "affordable", while prevention and immunization itself were considered a "public good".

Canada has adopted national legislation due to the COVID-19 pandemic connected to compulsory licensing. The legislation, denominated as the COVID-19 Emergency Response Act, is connected to the national law on patents and allows procurement of medicines and equipment due to a public health crisis under COVID-19 (SWLAW, 2020); (Laws-louis, 2020). The Canadian government already had experience in applying for compulsory licensing because in 2001, due to terrorist attacks caused by Antrax, Canada asked the only manufacturer of Ciprofloxacin, the German company Bayer, for a compulsory licence. On that occasion, the Canadian government claimed that German Bayer did not have adequate capacity for the crisis and the production of sufficient quantities of this antibiotic, which elicited a strong response from Bayer, who believed that the Canadian government did not harmonize the Patent Act to apply for generic production (Spurgeon, 2001). However, in 2021, the Canadian pharmaceutical company Biolyse agreed to forward 15 million doses to Bolivia if the Canadian government granted compulsory licensing. However, Johnson \& Johnson has denied such a request and disagrees with the generic production of this vaccine even though slightly more than $5 \%$ of the population in Bolivia has been vaccinated.

Chile is another country that has adopted national legislation in order to prepare for compliance with the requirements of the TRIPS Agreement regarding compulsory licenses during the Covid-19 pandemic. This decision of the 
Government of Chile was made in accordance with the previous request of the WHO in order to collect all the necessary data on the necessary drugs and vaccines, including the costs of research and development, import, production, etc.

Ecuador has followed examples from around the world and has also been involved in the potential for compulsory licensing through the TRIPS Agreement and as a member of the World Trade Organization. The Ecuador National Assembly passed the 20th of March 2020 decision for a resolution by the Ecuador government and the Ministry of Health to seek compulsory licensing during COVID-19. This decision contributed to a declaration in which the President of Ecuador and the Ministry of Health resolved administrative issues related to obtaining compulsory licensing, while the Public Health Sector was responsible for obtaining compulsory licensing for non-commercial use or production and import of necessary drugs and vaccines (Education, Culture, Science and Technology Commission of the National Assembly of Ecuador, 2020).

\section{THE IMPACT OF THE SELECTED PARAMETERS ON THE DECISION TO REQUEST/PREPARE FOR THE COMPULSORY LICENSING DURING THE COVID-19 PANDEMIC}

When looking at economic parameters, it is important to note that the basic economic indicator, Gross Domestic Product, is negative globally for 2020 (as a percentage change on an annual basis). The situation is the same with the observed countries when analysing the amount of Gross Domestic Product as well as the percentage change on an annual basis (comparing 2019 with 2020; data for 2021 was not used at a quarterly level). Thus, for selected countries that needed to prepare for or apply for compulsory licensing during the COVID-19 pandemic, Gross Domestic Product change is negative and for Ecuador is-11\% (the highest negative change), for France is-9.8\% while for Canada and Chile is-7.1\%. Russia with-4.1 and Israel with $-5.9 \%$ are better-ranked when considering GDP percentage change in 2020 (Table 1). 
Table 1. Real GDP and percentage change for selected countries (Knoema, 2021)

\begin{tabular}{|c|c|c|c|c|}
\hline Country & $\begin{array}{c}\text { Real GDP 2019 in } \\
\text { billions of USD) }\end{array}$ & $\begin{array}{c}\text { Real GDP 2020 } \\
\text { (in billions of } \\
\text { USD) }\end{array}$ & $\begin{array}{c}\text { Growth 2019 } \\
\text { (percentage } \\
\text { change) }\end{array}$ & $\begin{array}{c}\text { Growth 2020 } \\
\text { (percentage } \\
\text { change) }\end{array}$ \\
\hline Canada & 1,736 & 1,6 & 1,7 & $-7,1$ \\
\hline Chile & 282,3 & 245,4 & 1,1 & $-7,1$ \\
\hline Ecuador & 107,4 & 93,1 & 0,1 & -11 \\
\hline Hungary & 161 & 149 & 4,9 & $-6,1$ \\
\hline Israel & 394,7 & 383,4 & 3,4 & $-5,9$ \\
\hline Russia & 1,702 & 1,464 & 1,3 & $-4,1$ \\
\hline France & 2,715 & 2,551 & 1,5 & $-9,8$ \\
\hline
\end{tabular}

In the following, we observed the impact of the COVID-19 pandemic on the population of the observed countries. As part of that analysis, we observed that Israel had the highest rate of the SARS-COV2 virus infection with approximately 49,000 infected per million inhabitants, while France had about 40,000 patients per million inhabitants (2019-2020). Chile and Hungary had just over 30,000 infected per million inhabitants, while Ecuador had the fewest of the selected countries during 2020, with about 12,000 infected per million inhabitants (Table 2).

Hungary had the highest number of deaths from the SARS-COV2 virus in the period 2019-2020, while France had 958 deaths per million inhabitants (among the highest in the world). From the selected countries, Israel and Russia had the smallest numbers, around 380 deaths per million inhabitants (Table 2). 
Table 2. Pandemic impact on population for selected countries

(Ourworldindata.org, 2021)

\begin{tabular}{|c|c|c|c|c|}
\hline Country & $\begin{array}{c}\text { Covid-19 patients } \\
\text { in 2020 } \\
\text { (per million of } \\
\text { population) }\end{array}$ & $\begin{array}{c}\text { Covid-19 deaths } \\
\text { in 2020 } \\
\text { (per million of } \\
\text { population) }\end{array}$ & $\begin{array}{c}\text { vaccinated } \\
\text { population in 2020 } \\
\text { (as \% of total } \\
\text { population) at least } \\
\text { one dose received }\end{array}$ & $\begin{array}{c}\text { vaccinated } \\
\text { population in 2021 } \\
\text { until june (as \% of } \\
\text { total population) at } \\
\text { least one dose } \\
\text { received }\end{array}$ \\
\hline Canada & $15,484.25$ & 417.62 & $0.26 \%$ & $58.31 \%$ \\
\hline Chile & $31,856.37$ & 868.7 & 0 & $56.70 \%$ \\
\hline Ecuador & $12,045.08$ & 795.44 & 0 & $9.20 \%$ \\
\hline Hungary & $33,385.33$ & 987.23 & 0 & $53.90 \%$ \\
\hline Israel & $48,900.70$ & 384.15 & $11.44 \%$ & $63 \%$ \\
\hline Russia & $21,429.81$ & 385.59 & $0.55 \%$ & $11.45 \%$ \\
\hline France & $39,631.40$ & 958.48 & 0 & $38.98 \%$ \\
\hline
\end{tabular}

Of the observed countries, Russia, Chile and Canada have previous experience with compulsory licensing. Namely, Russia has submitted a request for lenalidomide (medical indication for Leprosy, Tuberculosis, AIDS, and Multiple myeloma) and has only one previous request. Unlike Russia, Ecuador had more experience with compulsory licensing and had a total of 11 such claims (related to HIV/AIDS, Cancer, and Rheumatoid arthritis). Chile had one compulsory licensing request relating to HCV medicines.

From the analysis, it can be concluded that countries like France and Hungary that did not have previous experience with compulsory licensing were actively preparing to use this option precisely because of the severity of the negative impact brought to them by the COVID-19 pandemic in health and economic terms. Israel turned to compulsory licensing in 2020 (the earliest in relation to other countries), which showed a certain awareness and commitment to finding a solution to the problem that arose, and above all, it is reflected in a large number of infected patients during 2020. In addition to this thesis, the fact that Israel achieved the highest rate of vaccinated population in 2020, unlike other observed countries, 
speaks of determination to find a solution and agility. It is interesting that Russia, despite good control of the economic and health impact of the COVID-19 pandemic and the fact that it produced the vaccine in 2020 , still has a relatively low percentage of the vaccinated population and, in the meantime, has applied for compulsory licensing for the potential treatment of the SARS-COV2 virus.

\section{CONCLUSION}

This paper has shown the importance and use of the flexibility provided by the TRIPS Agreement (compulsory licensing and Paragraph 6) both in earlier years and during the COVID-19 pandemic. The use of compulsory licensing, as well as other flexibilities during public health crises, is something that would be recommended for wider use and a larger number of requirements. Within the chapter, we also quoted Nobel laureate Joseph Stiglitz and his views on the situation with the HIV/AIDS epidemic in Thailand when they were not approved for generic production of drugs for this deadly disease. We believe that they should be repeated in the concluding remarks as a vox populi: "a death warrant for thousands of people in the poorest countries of the world". In the case of the COVID-19 pandemic, a paradoxical situation has arisen which suggests a vague interpretation in which vaccines are not a public good but prevention and immunization are, while vaccines should be procured at an affordable cost to the United States of America and contrary to the consent of more than 100 member states of the WTO.

In this chapter, we analysed the total number of requests for flexibilities related to pharmaceuticals through the TRIPS Agreement, and we noticed that the largest number of requests was connected to compulsory licensing and Article 31 . This could be explained by the type of requests made and by the requirements for obtaining such a request (both legal and operational).

In addition, we showed the number of compulsory licensing requirements in relation to the world's regions. The largest number of requests originated from the region of Africa (73), followed by Latin America (27), and the smallest number of requests came from Europe (16) and North America (5). This shows the increasing interest of developed countries within the European and North American regions for the flexibilities, but compared to the "traditional high-profile users" (e.g. African countries), there is still a high difference noted. This could be explained by the type of health emergency (crisis) in developed countries and their healthcare system approach contradicting the same in underdeveloped countries.

Countries' prior experience in flexibilities was shown during the COVID-19 pandemic, and out of selected countries compulsory licensing was requested by Hungary, Russia, and Ecuador, and in 2020 it was requested by Israel for the COVID- 
19 pandemic. Of the observed countries, Russia, Chile and Canada have previous experience with compulsory licensing. As mentioned, countries like France and Hungary did not have previous experience with compulsory licensing but were actively preparing to use this option precisely because of the severity of the negative impact brought to them by the COVID-19 pandemic in both health and economic terms (e.g., Canada adopted national legislation due to the COVID-19 pandemic connected to compulsory licensing). The number of infected within the population was high, together with the economic impact (measured as a GDP percentage drop), which was considered to have a significant impact on the decision to request certain flexibilities or prepare for them through national legislation.

In the future, it would be beneficial that transfers of knowledge and patent rights encounter a higher degree of understanding, especially when it comes to global or national health crises. By analysing previous uses of compulsory licensing, as well as those related to the COVID-19 pandemic, we concluded that there was not enough interest by states in using these flexibilities, and various reasons might initiate the state's desire to apply for compulsory licensing. As we have noticed, countries such as Hungary and France considered such flexibilities of the TRIPS Agreement for the first time during the COVID-19 pandemic, due to the great economic and health pressure that the pandemic brought during 2020. Other observed countries have previous experiences with compulsory licensing that have not always been positive but have found a potential source to address the nation's health problems in times of this global health crisis.

\section{REFERENCES}

Ćuzović, S. Ćuzović, Dj. Stamenovic, M. (2019).Globalizacija.-savremeni aspekti ekonomije, trgovine i zdravstva[Globalization - modern aspects of economy, trade and health]. Beograd, Ekonomski Fakultet Univerziteta u Nišu.

Education, Culture, Science and Technology Commission of the National Assembly of Ecuador. (2020). Resolution for Compulsory licensing of Patents Relating to Coronavirus, Comisión Especializada Permanente de Educación, Cultura y Ciencia y Tecnología de la Asamblea Nacional [Education, Culture, Science and Technology Commission of the National Assembly], March 20, 2020 (Ecuador).

EPO. (2020). European Patent Convention and the Patent Cooperation Treaty, retrieved from https://www.epo.org/law-practice/legal-texts/html/epc/2020/e/ ma1.html. Accessed 20 May 2021.

Jelisavac Trosic, S. Todić,D. Stamenovic, M. (2018). Svetska trgovinska organizacija - životna sredina i zdravstvena zaštita [World Trade Organization - Environment and Health]. Beograd, Institut za medjunarodnu politiku i privredu. 
Jelisavac-Trosic, S. (2020). Serbia in EU and WTO negotiations. Revizor, 23(91-92); 49-55.

Kass, D. (2020). Israel Defies AbbVie IP To Import Generic Drugs For COVID-19. March 19, 2020, retrieved fromhttps://www.law360. com/articles/1255079? scroll=1\&related=1. Accessed24 March 2021.

Knoema. (2021). GDP Canada, retrieved fromhttps://knoema.com/atlas/topics/GDP. Accessed 24 May 2021.

Laws-louis. (2020). COVID-19 Emergency Response Act, S.C. 2020, C-13 (Can.), retrieved from https://laws-lois.justice.gc.ca/eng/annualstatutes/2020_5/. Accessed24 May 2021.

Medicines Law \& Policy, (2021). Trips flexibilities, retrieved from http://trips flexibilities.medicineslawandpolicy.org/. Accessed 1 June 2021.

Ourworldindata.org (2021). COVID19 per country, retrieved from https://ourworld indata.org/. Accessed24 May 2021.

Proyecto de Resolución $N^{\circ} 896$, Resolution for Involuntary Licensing of Patents Relating to Coronavirus, Cámara de Diputadas y Diputados [Chamber of Deputies], Mar. 17, 2020 (Chile).

Rabrenović, M., Popov, D., \& Stamenović, M. (2020). Stepen ostvarene liberalizacije ekonomije Srbije u procesu pristupanja Svetskoj trgovinskoj organizaciji [The degree of achieved liberalization of the Serbian economy in the process of joining the World Trade Organization]. Megatrend revija, 17(3), 65-78.

Spurgeon,D. (2001).Canadian Government Almost Swamped by Ciprofloxacin. 323 British Med. J. 1026.

Stamenović, M. (2020). Treba li očekivati povećanje korporativne špijunaže u farmaceutskoj industriji u budućnosti?[Should we expect an increase in corporate espionage in the pharmaceutical industry of tomorrow?]. Revizor, 23(91-92), 37-47.

Stamenovic, M. (2020a). Quantitative analysis of biotechnology patents nexus to national economies and policies. Revizor, 23(89-30), 7-17.

Stiglitz, J. (2007). Making Globalization Work: The next Steps to Global Justice. London: Penguin.

Swlaw. (2020), retrieved from https://www.swlaw.com/assets/pdf/news/2020/12/ 01/CompulsoryPatentLicensingintheTimeofCOVID-19ViewsfromtheUnited States,Canada,andEurope.pdf. Accessed 24 May 2021.

Third World Network. (2020). Third World Network (2020), WHO: Leaders call COVID-19 vaccines a global good, retrieved from https://twn.my/title2/health. info/2020/hi200511.htm. Accessed 10 June 2021. 
USTR.gov. (2020). US-China Economic and Trade Agreement, retrieved from https://ustr.gov/sites/default/files/files/agreements/phase\%20one\%20agreem ent/Economic_And_Trade_Agreement_Between_The_United_States_And_ China_Text.pdf. Accessed 20 May 2021.

WHO, (2020). Making the response to COVID-19 a public common good, retrieved from https://www.who.int/docs/default-source/coronaviruse/solidarity-call-toaction/solidarity-call-to-action-01-june-2020.pdf?sfvrsn=a6c4b03d_4. Accessed 1 June 2021.

Wong, H. (2020). The case for compulsory licensing during COVID-19. University of California, Berkeley, School of Law, USA, 10(1), retrieved fromwww.jogh.org. Accessed 20 May 2021.

WTO. (2021). Fact Sheet: TRIPS and Pharmaceutical Patents, retrieved from https://www.wto.org/english/tratop_e/trips_e/factsheet_pharm02_e.htm. Accessed 20 May 2021. 